\title{
Comparative Analysis of Different Treatments Effects on Stylosanthes Guianensis Production Parameters in Imbo, Natural region of Burundi
}

\author{
BANDUSHUBWENGE Denis ${ }^{* 1}$, KWIZERA Chantal ${ }^{2}$, MBONIHANKUYE Cyrille ${ }^{3}$ \\ ${ }^{1}$ University of Burundi, Faculty of Agriculture and Bio Engineering, Department of vegetal productions \\ Sciences, B.P 2940 Bujumbura, Burundi \\ ${ }^{2}$ University of Burundi, Faculty of Agriculture and Bio Engineering, Department of Environment Sciences \\ and Technologies, B.P 2940 Bujumbura, Burundi \\ ${ }^{3}$ Agronomic Sciences Institute of Burundi (ISABU)
}

\begin{abstract}
In Burundi, the major problem for livestock is the lack of sufficient nutrients needed for its growth and development due to Burundi higher population growth rate which put a pressure on arable lands and pastures leading to grass pastures reduction. However the concentrates that can be used alternatively are not only insufficient, but also very expensive under the local farmer conditions. In the Burundi, livestock reduction was recorded while it occupies an important place in Burundian life, especially for smallholders to whom it plays a major role in terms of social life, health and income generation. Fortunately, stylosanthes Guianensis has been identified as an herbaceous forage legume with potential protein supplements of better impacts on livestock growth, development and production. It is more accessible to smallholder, whence this study has been carried out to improve stylosanthes production for better livestock feeding. The experiment has considered six seedling spacing as treatments to analyze the treatment which could effectively improve the stylosanthes production parameters in Imbo natural region. These treatments $(T 1(40 \mathrm{~cm} X 5 \mathrm{~cm}) ; T 2(40 \mathrm{~cm} X 10 \mathrm{~cm}), T 3(50 \mathrm{~cm} X 5 \mathrm{~cm}), T 4(50 \mathrm{~cm} X 10 \mathrm{~cm}), T 5(60 \mathrm{~cm} \mathrm{X} 5 \mathrm{~cm}), T 6(60 \mathrm{~cm} X 10 \mathrm{~cm}))$ were ranged in three blocs completely randomized with three replications. Data were sampled at the $8^{\text {th }}, 10^{\text {th }}, 12^{\text {th }}, 14^{\text {th }}, 16^{\text {th }}, 18^{\text {th }}$, and the $21^{\text {st }}$ weeks after germination by recording as parameters: plant height, ramifications number, plant water content, green and dry matters. All data were analyzed through SPSS at P<0.05 for significative difference. The results showed no significant difference among treatments for plant height but highlighted treatments $T 2$ as the effective treatments in increasing plant growth especially in developing period. This treatment $T 2$ also showed positively effects on ramifications number comparatively to others. Moreover, T2 treatment significantly improved plant water content, green matter and dry matter. This study suggested treatment $T 2(40 \mathrm{~cm} X 10 \mathrm{~cm})$ as the effective treatment which could be used for improving stylosanthes production parameters and productivity as well in the Imbo region.
\end{abstract}

Keywords: Stylosanthes Guianensis, Different treatments, Production parameters, Imbo region.

\section{INTRODUCTION}

In Burundi, the major problem for livestock is the lack of sufficient nutrients needed for its growth and development due Burundi higher population growth rate ${ }^{[1]}$ which put a pressure on arable lands and pastures leading to grass pastures reduction. Furthermore, the concentrates that can be used alternatively are not only insufficient, but also very expensive under the local farmer conditions. Although livestock has the ability to select and consume a wide range of forages, tree leaves and crop residues, there still a feed shortage, due to seasonal effect with abondant forages only during the wet season and dry out in the dry season ${ }^{[2]}$, whence deficiency in energy, protein and essential minerals and vitamins for livestock leading to its reduction while it occupies an important place in Burundian life especially for smallholders by playing a major role in terms of social life and income generation. However herbaceous forage legumes Stylosanthes species have been identified as potential protein supplements for livestock since they contain high crude protein (150 -300 g/kg DM), minerals and vitamins that are needed for livestock growth and development ${ }^{[3]}$. Stylosanthes guianensis is a leguminous perennial herb with an erect form, many branches and trifoliate leaves ${ }^{[4-5]}$. It is native to South America and adapts to a wide range of soil and very resistant to various weather conditions. 
Stylosanthes is a short-lived perennial legume, very tolerant of low fertility and acid soils ${ }^{[3]}$. Usually grown as a cover crop, Stylosanthes is self-fertile and effectively suppresses weeds. Moreover, it can help prevent soil erosion by $70 \%$ and enhance soil nutrients ${ }^{[6]}$. Stylosanthes has assumed a very important position as a pasture legume for grassland but also for degraded forest area and waste lands ${ }^{[7]}$. It has been found promising and combines both disease resistances with other favorable agro-forestry characteristics. Based on foregoing research, Stylosanthes guianensis is among several legumes which produced good biomass ${ }^{[8]}$. It is a good feed supplement for most animals and can be used fresh or dried for hay and leaf meal ${ }^{[3]}$. Stylosanthes is fairly palatable to livestock and improves its growth and development ${ }^{[2]}$. It contains $33-40 \%$ crude fibre, $0.1-0.2 \% \mathrm{P}, 0.8-1 \% \mathrm{Ca}$, $1.2-1.8 \% \mathrm{~K}, 0.3-0.8 \% \mathrm{Mg}$, a trace $0.02 \% \mathrm{Na}$ and $0.1-0.8 \% \mathrm{Cl}$ in the dry matter ${ }^{[9]}$. Considering stylosanthes' impact on the livestock growth, development and production, as well as its accessibility to smallholder farmers compared to the concentrates, the improvement of Stylosanthes productivity is needed especially in Burundi where the effectiveness of legumes use in the animals ration remains low due to grass dominance in the grazing land and Burundian habit of using Pennissetum purpureum and Setaria sphacelata grasses as supplement, while livestock nutrient deficiency was reported by relying on these grasses feed only. This study aimed to analyses the effects of different treatment on Stylosanthes production parameters in Imbo natural region conditions to find a treatment which can effectively improve stylosanthes growth, development and production whence enhancement of livestock productivity through better feeding leading to improved households food security and livelihood.

\section{MATERIALS AND METHODS}

\subsection{Site description and soil properties}

The experimentation site was located in the Imbo region displayed in this following map ${ }^{[10]}$

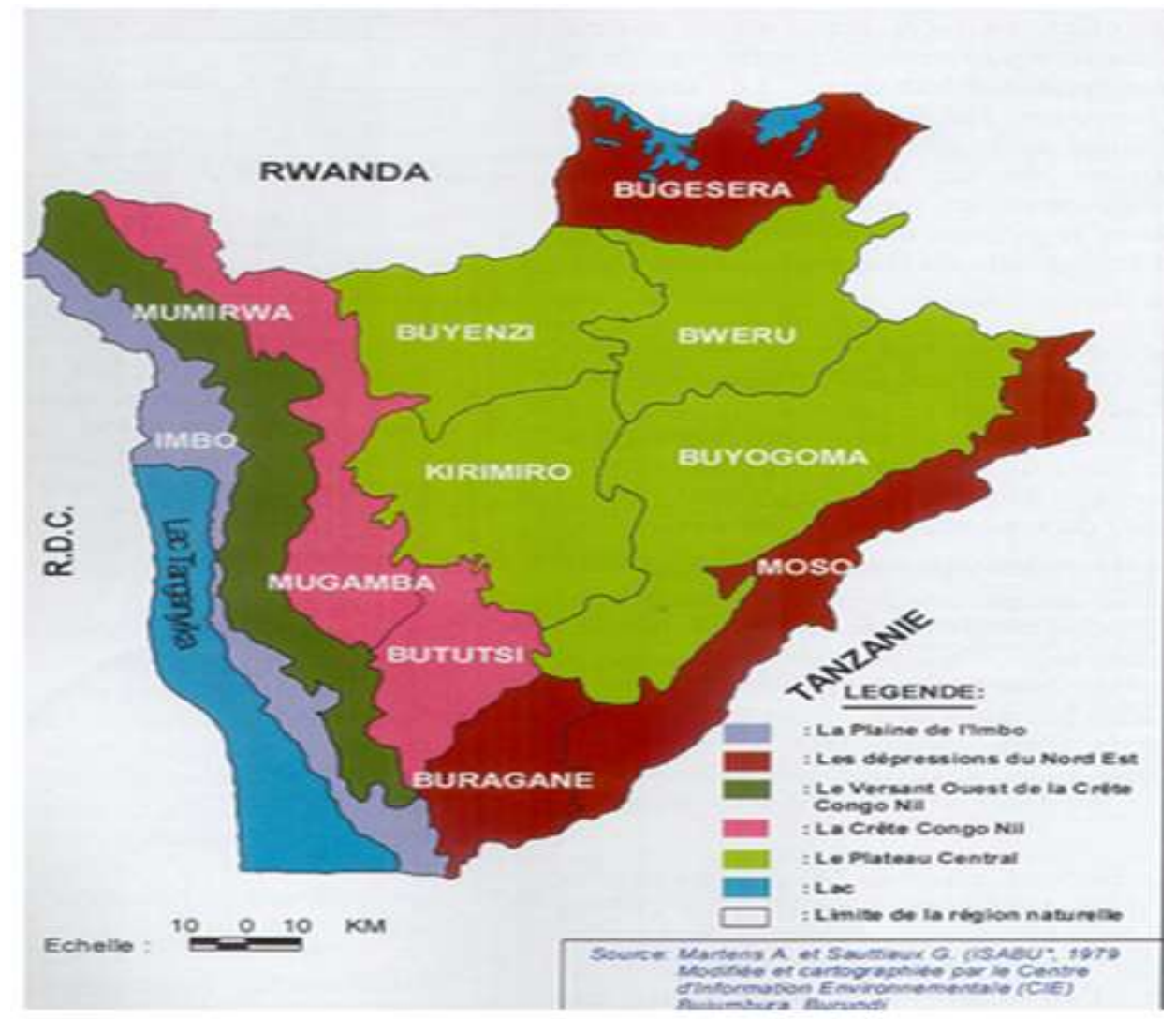

\section{Photo 1 : Burundi natural regions map}

Specifically, the experiment was carried out at Burundi University in the faculty of Agronomy. The recorded average precipitation was $106.73 \mathrm{~mm}$ with $25^{\circ} \mathrm{C}$ as mean temperature and an altitude of $883.44 \mathrm{~m}$. The soil texture was characterized by $30.84 \%$ of clay and $\mathrm{C}$ of $1.36 \%$.

\subsection{Experiment design}

The experiments has considered six seedling spacing considered as treatments $(\mathrm{T})$ : $\mathrm{T} 1(40 \mathrm{~cm} \mathrm{X} 5 \mathrm{~cm}) ; \mathrm{T} 2(40 \mathrm{~cm} \mathrm{X} 10 \mathrm{~cm}), \mathrm{T} 3$ $(50 \mathrm{~cm}$ X $5 \mathrm{~cm}), \mathrm{T} 4(50 \mathrm{~cm}$ X $10 \mathrm{~cm}), \mathrm{T} 5(60 \mathrm{~cm}$ X $5 \mathrm{~cm})$, and T6 $(60 \mathrm{~cm} \mathrm{X} 10 \mathrm{~cm})$, ranged in three blocs completely randomized with three replications for each as shown below. 


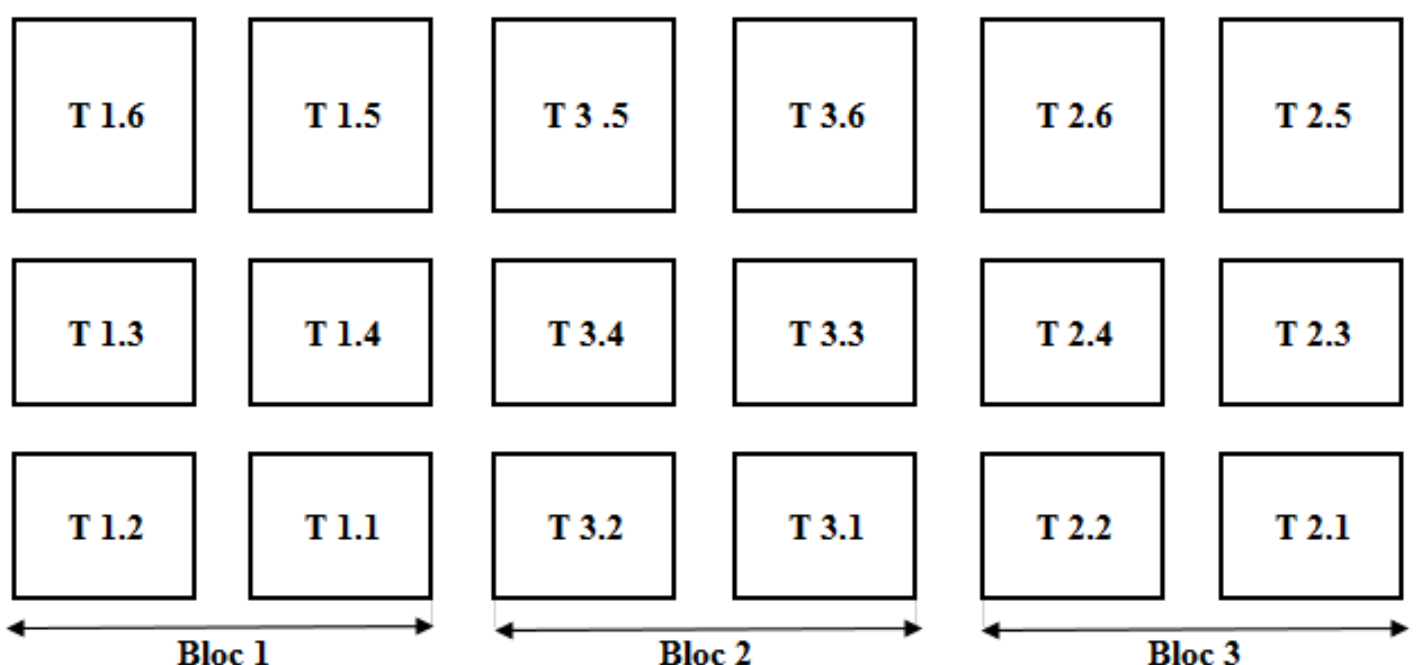

Figure 1. Experiment design

For each treatment, the first and the second numbers show the replication and the treatment number respectively.

Before sowing, the fertilizers were applied as recommended by Burundi Agricultural Sciences Institute (ISABU), while during the growth period, diseases and pests were normally controlled.

\subsection{Sampling and data collection:}

Data were sampled at the $8^{\text {th }}, 10^{\text {th }}, 12^{\text {th }}, 14^{\text {th }}, 16^{\text {th }}, 18^{\text {th }}$, and the $21^{\text {st }}$ week after germination. The recorded parameters were plant height, ramifications number, water content, green matter and dry matter.

\subsection{Statistical analysis:}

All data were processed with applied Excel 2007 and SPSS. Figures were made by using Excel, while comparison between treatments were conducted through LSD (least significant difference) and SPSS at $P<0.05$.

\section{RESULTS}

\subsection{Effects of different treatments on plant height $(\mathrm{PH})$}

The results on plant height $(\mathrm{PH})$ were summarized in Figure 2. Plant height increase with data record date with a linear growth rate. In the first days ( $8^{\text {th }}$ week), there was no significance difference between treatments.

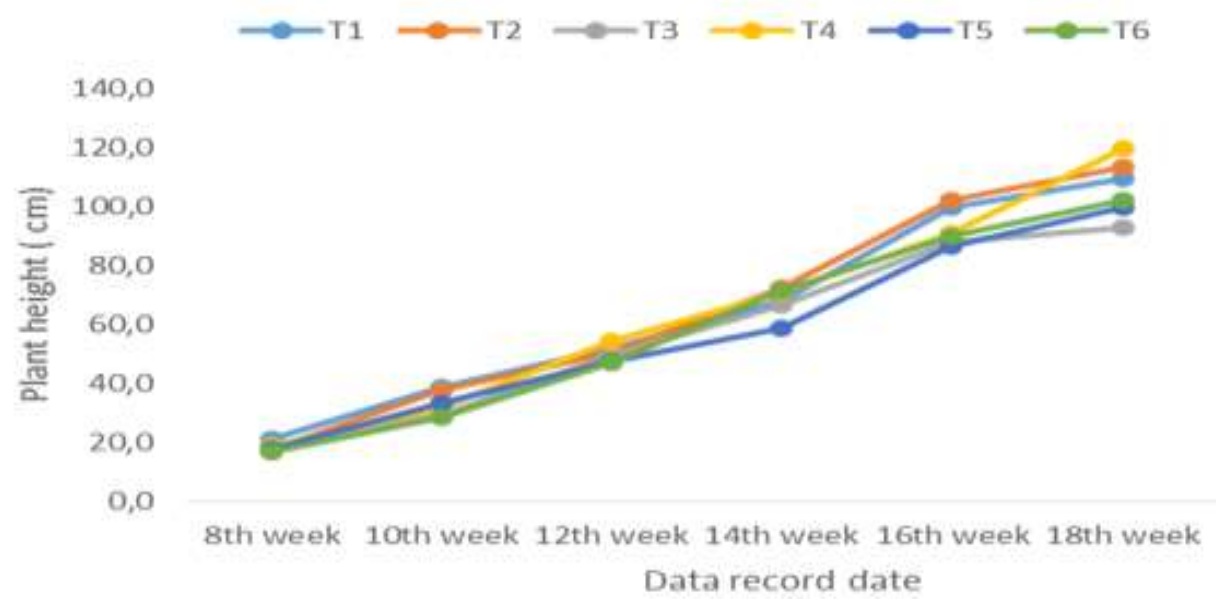

Figure 2. Effects of different treatments on plant height (PH) 
The highest PH of $21.3 \mathrm{~cm}$ was recorded for the T1 method and minimum for T6 with $17 \mathrm{~cm}$. The same trend was observed on $10^{\text {st }}$ and $12^{\text {th }}$ week, the maximum PH was recorded for T1 with $39 \mathrm{~cm}$ and $52 \mathrm{~cm}$ respectively, while the minim of 28 and $47.3 \mathrm{~cm}$ was obtained by T6. At the $14^{\text {th }}$ week, the trend changes, the highest plant height was recorded for T2 $(72 \mathrm{~cm})$ and minimum for T3 $(66.7 \mathrm{~cm})$. Similarly, on $16^{\text {th }}$, the tallest plant was still recorded by T2 and minimum T5 $(86 \mathrm{~cm})$. However in the last days the maximum was recorded by T4 with $120 \mathrm{~cm}$ and did not significantly differed to the following treatment $\mathrm{T} 2 \mathrm{of} 113 \mathrm{~cm}$ but both significantly differed to T3 treatment with shortest plant of $93 \mathrm{~cm}$.

\subsection{Influences of different treatments on ramifications number $(R L)$}

Branch ramification is a notable trait that varies both within and among species. It serve for hydraulic and biomechanical functions as reported but foregoing researchers ${ }^{[11-12-13-14-15]}$. Furthermore, branch ramification may be linked to reproductive characters $^{[15-16]}$, whence this studies has assessed its evolution as summed up in the figure 3

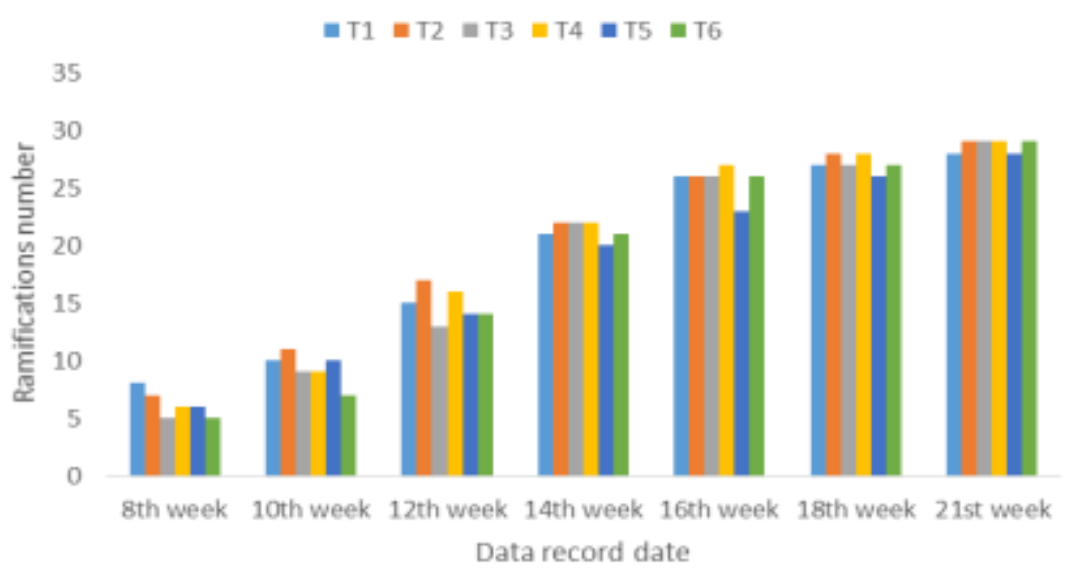

Figure 3. Response of ramifications number to different treatments

The outcomes on ramifications number shows no significant difference between treatments. Specifically, on the $8^{\text {th }}$ week, the ramifications maximum value was recorded for treatments T1 and T2 with 8 and 7 ramifications respectively. The minimum of 5 ramifications was observed for both $\mathrm{T} 3$ and $\mathrm{T} 6$. In the following days (12 $2^{\text {th }}$ week), ramifications highest number of 11 ramifications was observed for T2, followed by T1 and T3 with both 10 ramifications and minimum for T6 with 7 ramification. The same trend was observed on the $14^{\text {th }}$ week where the optimum ramifications number was observed for $\mathrm{T} 2$ with 22 ramifications as well as for $\mathrm{T} 3$ and $\mathrm{T} 4$ which got the said value, while the minimum of 20 ramifications was observed for T5. The same pattern was observed on the $18^{\text {th }}$ and $21^{\text {th }}$ where treatment $\mathrm{T} 2$ still in the first place without no significance difference observed between treatments and minimum for treatment $\mathrm{T} 5$.

\subsection{Effects of different treatment on plant water content $(P W C)$}

Plant water content is one of the most common physiological parameters limiting efficiency of photosynthesis and biomass productivity ${ }^{[16-17]}$. It is a very important parameter in determination of plant drought and salinity tolerance due to water stress which restricts transpiration including closure of stomata and water evaporation from leaf surface. Whence it has been recorded in this study as displayed in figure 4. 


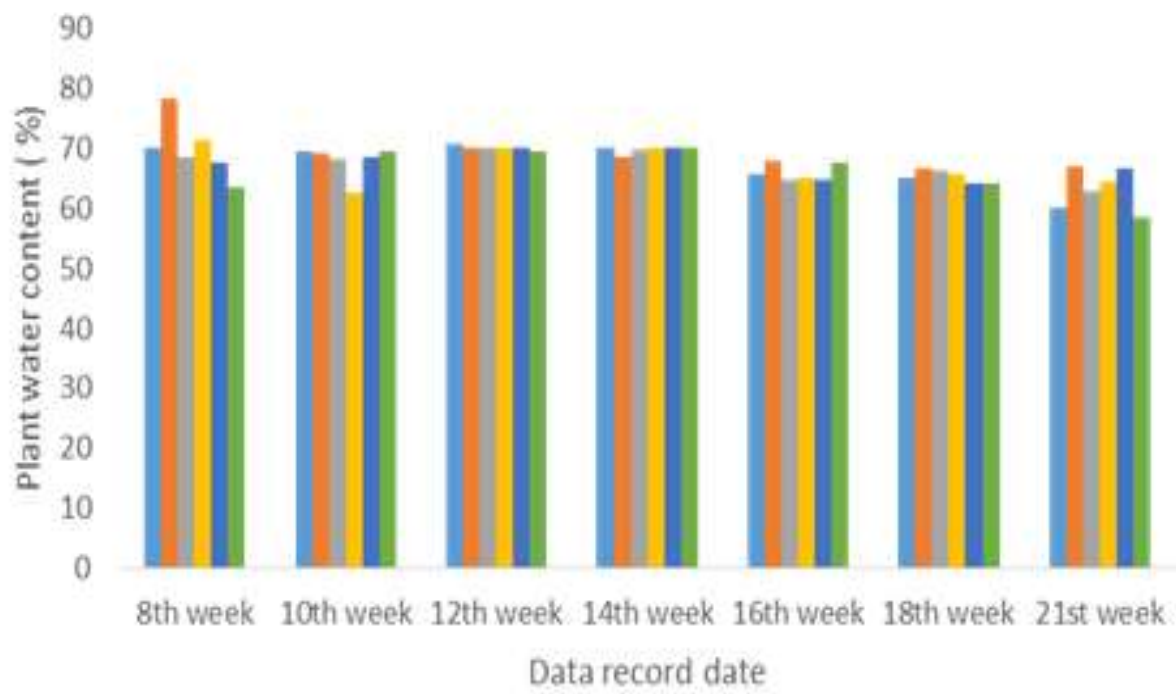

Figure 4. Effects of different treatments on plant water content (PWC)

Considering this figure, the plant water content (PWC) was effectively influenced by the applied treatment. Specifically, considering the $8^{\text {th }}$ week, the highest value was recorded for T2 treatment with $78.4 \%$, while the minimum was observed for T6 treatment of $63.6 \%$. Regarding to the $10^{\text {th }}$ week, the maximum PWC value of about $69 \%$ was observed for both treatments T2 and T6, whereas T4 got the minimum by $62.5 \%$. On $12^{\text {th }}$, treatment $\mathrm{T} 2$ still in the first place with $70.2 \%$ of water content. The same trend was observed in the last weeks $16^{\text {th }}, 18^{\text {th }}$ and $21^{\text {th }}$ where treatment $\mathrm{T} 2$ got the maximum water content of $67.8 \%, 66.6 \%$ and $67 \%$ respectively comparatively to others. However the minimum of $64.6 \%$ and $64 \%$ was observed for T5 on the $16^{\text {th }}$ and $18^{\text {th }}$ respectively, while on the $21^{\text {th }}$ the minimum value of $58 \%$ was observed for treatment T6.

\subsection{Different treatment effects of on green matter (GM)}

Green matter evolution is summed up in the following Figure 5. It increase with data registration date following the relation GM $8^{\text {th }}<$ GM $10^{\text {th }}<$ GM $12^{\text {th }}<$ GM $14^{\text {th }}<$ GM $16^{\text {th }}<$ GM $18^{\text {th }}<$ GM $21^{\text {st }}$. Clearly, on the $8^{\text {th }}$ week, there was no significance difference between treatments, highest value of $14 \mathrm{~g}$ was observed for T2 and T3 with $13 \mathrm{~g}$ for both treatments, while the lowest of $7 \mathrm{~g}$ was recorded for $\mathrm{T} 6$ treatment.

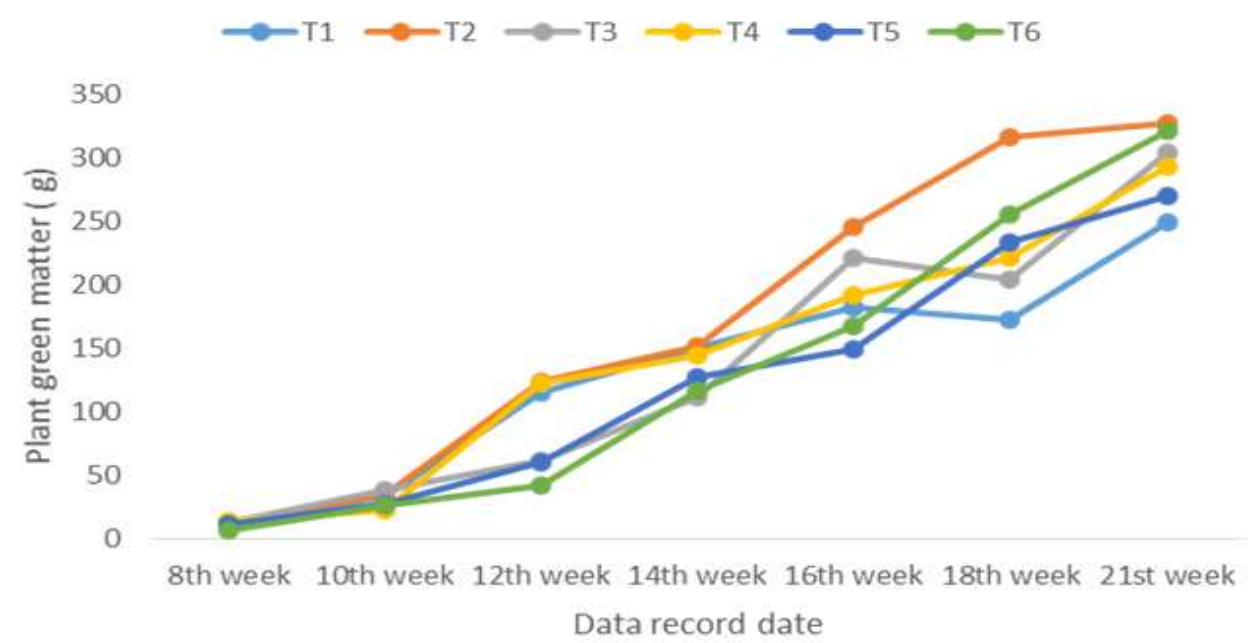

Figure 5. Effects of different treatments on green matter content

On the $10^{\text {th }}$ week, treatment T3 (39g) and T2 (35 g) occupied the first and the second place, while treatment T4 (23 g) was the last one. On the $12^{\text {th }}$ week, green matter maximum value was observed for T2 treatment with $124 \mathrm{~g}$, followed by T3 of $123 \mathrm{~g}$, while the minimum of $42 \mathrm{~g}$ was recorded for T6. The same trend was observed on the $14^{\text {th }}$ week where the first highest value of $152 \mathrm{~g}$ was observed for T2, the second for T1 with $151 \mathrm{~g}$, and the lowest of $111 \mathrm{~g}$ for T3 treatment. On the $16^{\text {th }}$ week, higher significant difference was observed between treatments. Specifically, the optimum value was still recorded for T2 treatment with $246 \mathrm{~g}$ which 
significantly differed to others with $\mathrm{P}<0.05$. It was followed by T3 of $222 \mathrm{~g}$, and minimum for treatment T5 of $149 \mathrm{~g}$. On the $18^{\text {th }}$ week, as it can be seen from figure 5 , the same evolution pattern was observed, with a maximum green matter value for $\mathrm{T} 2$ ( $317 \mathrm{~g}$ ) and minimum for T1 (173 g). The same trend was also observed on the $21^{\text {st }}$ weeks where highest value of $327 \mathrm{~g}$ was observed for $\mathrm{T} 2$ which significantly differed $(\mathrm{p}<0.05)$ from other treatments. The following was $\mathrm{T} 6$ with $321 \mathrm{~g}$ and minimum treatment $\mathrm{T} 1 \mathrm{of}$ $250 \mathrm{~g}$.

\subsection{Effects of different treatments on dry matter (DM)}

The outcomes on dry matter were shown in figure 6. As for the green matter, dry matter increase with data registration date following the relation DM $8^{\text {th }}<\mathrm{DM} 10^{\text {th }}<\mathrm{DM} 12^{\text {th }}<\mathrm{DM} 14^{\text {th }}<\mathrm{DM} 16^{\text {th }}<\mathrm{DM} 18^{\text {th }}<\mathrm{DM} 21^{\text {st }}$.

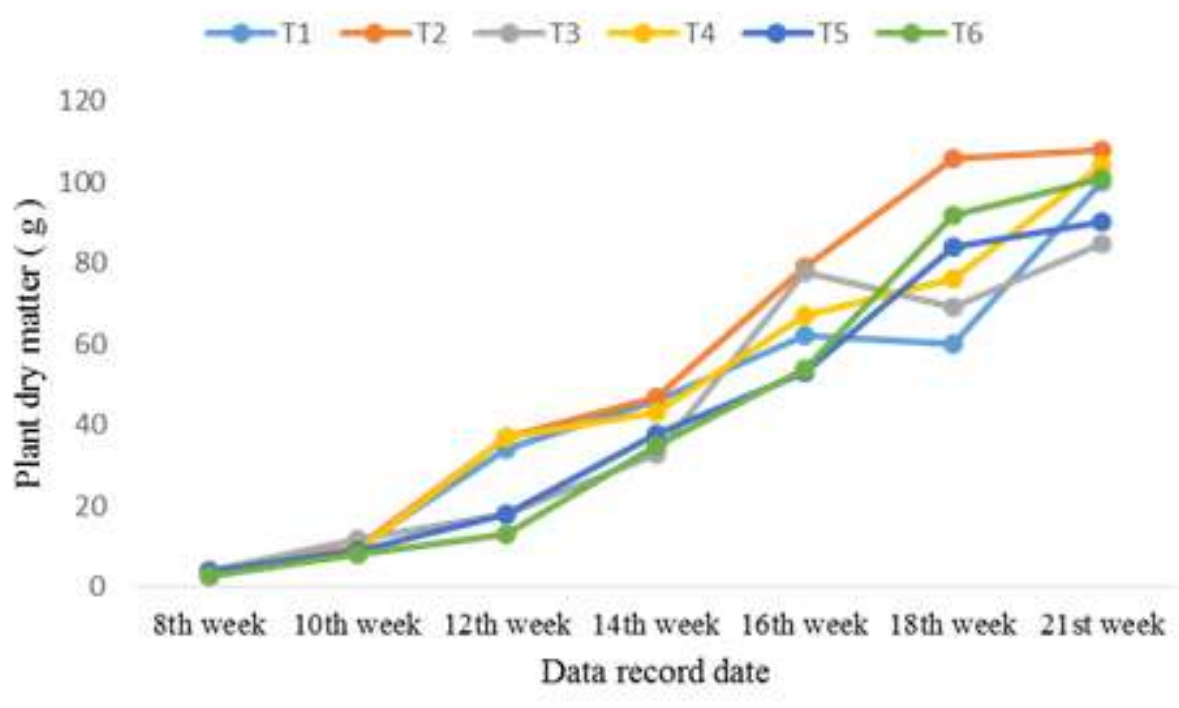

Figure 6. Dry matter evolution as influenced by different treatments

On the first weeks, no significance difference was observed, the value of dry matter per plant oscillates between 4 and $3 \mathrm{~g}$ on the $8^{\text {th }}$, while on the $10^{\text {th }}$ week, it value between 8 and $12 \mathrm{~g}$. However, on the $12^{\text {th }}$ week a little discrepancy was observed with highest value for T2 and T4 treatments with both $37 \mathrm{~g}$. The following was treatment T1 of $34 \mathrm{~g}$ and minimum for T6 with $13 \mathrm{~g}$. On the $14^{\text {th }}$ week, dry matter highest value was recorded for $\mathrm{T} 2(47 \mathrm{~g})$ followed by T1 of $46 \mathrm{~g}$, while T3 treatment got the minimum with $33 \mathrm{~g}$. On the $16^{\text {th }}$ week, the same trend was observed with highest value for $\mathrm{T} 2(79 \mathrm{~g})$ and presented significant difference from T5 (53 g) and T6 (54 g), treatments with minimum value. Similarly, on the $18^{\text {th }}$ week, maximum value was still recorded for T2 (106 g) which significantly differed from others with $\mathrm{p}<0.05$. The minimum was observed for $\mathrm{T} 1$ treatment with a dry matter $60 \mathrm{~g}$. The same dry matter evolution pattern was observed on the $21^{\text {st }}$ week, where the highest value was observed for $\mathrm{T} 2$, $108 \mathrm{~g}$, followed by $\mathrm{T} 4,104 \mathrm{~g}$, and the minimum for T3 of $85 \mathrm{~g}$.

\section{DISCUSSION}

The assessed parameters were effectively influenced by the used treatments. Regarding the plant height, although there was no significant difference among treatments in the first weeks, significant difference was observed later during development growth period with treatment T2 as the effective treatment in increasing plant growth. This may be attributed to the adequate seedling spacing, whence assimilation of more nutrients that plant need for growth. This support the results of Zubeldia and Gases (1977) who reported optimum plant growth through different spacing ${ }^{[18]}$. They endorse the result of Olivares et al. (2015) [19] who highlight Stylosanthes guianensis plant height Increments with applied treatments. Moreover, this treatment T2 significantly improved dry matter, leading to adequate crude protein enhancement as reported by foregoing researchers ${ }^{[20]}$, whence a greater positive effect on livestock health, leading to a little improvement of households food security and life to whom livestock is an integral part of many subsistence by providing: income, milk, meat, and manure. Furthermore, treatment T2 significantly increased plant water content. However better plant water content allows to maintain favorable photosynthesis rates even with small stomatal opening ${ }^{[21]}$, whence synthesis of many nutrient that the plant needs for its growth and development leading to green matter increment as has been found in this study. Thereby a very nutritious production for livestock. Considering all these, treatment $\mathrm{T} 2$ could be considered as an effective treatment which could improve stylosanthes production parameters and 
productivity as well in the region.

\section{CONCLUSION}

The outcomes highlighted better effects of $\mathrm{T} 2$ treatment $(40 \mathrm{~cm} \mathrm{X} 10 \mathrm{~cm})$. It has played an important role in plant growth by increasing a little bit the average plant height and ramifications number. Furthermore, this treatment has significantly improved plant water content, green matter and plant dry matter. This study suggested $\mathrm{T} 2$ treatment as the effective treatment which can be used to improve stylosanthes production parameters in the region whence enhancement of livestock health leading to improved households food security and life.

\section{REFERENCES}

[1] Ministry of Agriculture and Livestock. Global agriculture and food security program. march 2012. Online at: https://www.gafspfund.org/sites/default/files/inline-files/2-Burundi\%20GAFSP\%20Proposal.pdf

[2] Phengsavanh Phonepaseuth 1997 Environmental adaptation of forages in Lao PDR. Livestock Development Division, DLF, MAF, Lao PDR.

[3] Norton, B. W. and Poppi, D. P. (1995) Composition and nutritional attributes of pasture legumes. In: J P F D'Mello and C Devendra (editors). Tropical legumes in Animal nutrition (CAB International) Wallingford, UK. 23-46

[4] Peoples, M. B., and E. T. Craswell, 1992: Biological nitrogen fixation: investments, expectations and actual contribution to agriculture. Plant Soil 141, 13-40

[5] Peoples, M. B., D. F. Herridge, and J. K. Ladha, 1995:Biological nitrogen fixation: an efficient source of nitrogen for sustainable agricultural production? Plant Soil 174, 3-28.

[6] Doanh, L. Q., and H. D. Tuan, 2004: Improving indigenous technologies for sustainable land use in northern mountainous areas of Vietnam. J. Mount. Sci. 1, 270-275

[7] Hazra CR (1997). Commercial Development of Stylosanthes Pasture. A component of the Forage Research Network in India.Trop. Grassland (31): 476-481

[8] Ackerly \& Donoghue (1998) Ackerly D, Donoghue M. Leaf size, sapling allometry, and Corner's rules: phylogeny and correlated evolution in maples (Acer) The American Naturalist. 1998;152:767-791. doi: 10.1086/286208.

[9] FAO, 2002: http://www.fao.org/ag/AGA/AGAP/FRG/AFRIS/Data/285.htm accessed 5 March, 2006.

[10] http://www.fao.org/nr/water/aquastat/countries_regions/BDI/BDI-CP_fra.pdf

[11] Corner (1949) Corner EJH. The durian theory or the origin of the modern tree. Annals of Botany. 1949;13:367-414. doi: 10.1093/oxfordjournals.aob.a083225.

[12] Ackerly DD, Donoghue $M J$;Leaf size, sapling allometry, and Corner's rules: phylogeny and correlated evolution in maples (Acer).Am Nat. 1998 Dec; 152(6):767-91

[13] Olson ME, Aguirre-Hernández R, Rosell JA. Universal foliage-stem scaling across environments and species in dicot trees: plasticity, biomechanics and Corner's Rules. Ecol Lett. 2009 Mar; 12(3):210-9.

[14] Bond \& Midgley (1988) Bond W, Midgley J. Allometry and sexual differences in leaf size. The American Naturalist. 1988;131:901-910. doi: 10.1086/284830.

[15] Midgley J, Bond W. Leaf size and inflorescence size may be allometrically related traits.Oecologia. 1989 Mar; 78(3):427429

[16] Shirley, M. N., Vincent, P. M., and Darryl, L. P. (1990). Abscisic acid accumulation and carotenoid and chlorophyll content in relation to water stress and leaf age of different types of citrus. J. Agr. Food Chem. 38, 1326-1334. doi: 10.1021/jf00096a007

[17] Arndt, S. K., Irawana, A., and Sanders, G. J. (2015). Apoplastic water fraction and rehydration techniques introduce significant errors in measurements of relative water content and osmotic potential in plant leaves. Physiol. Plantarum 155, 355368. doi: $10.1111 / \mathrm{ppl} .12380$ 
[18] Zubeldia, A. and J.L. Gases, 1977. The effect of spacing and the number of stem on the earliness and total yield of tomato cultivars. Prod. Vegetable, 7: 73-97

[19] Olivares J., Edison Valencia, and Ramsos-Santana. Seeding rates of Ubon Stylo (Stylosanthes guianensis) affect plant population density, growth and dry matter yield. Eco Flora Agro journal, $2015 . \quad$ Online at : https://www.researchgate.net/publication/309530820_Seeding_rates_of_Ubon_Stylo_Stylosanthes_guianensis_affect_plant_popul ation_density_growth_and_dry_matter_yield

[20] Tersur Akpensuen, Munza and Uchele Okpanachi. Effects of stage of growth on dry matter yield and nutrients composition of stylo (Stylosanthes guianensis cv. Cook) in Vom, Plateau State, Nigeria

[21] Larcher, W (2006) Ecofisiologia vegetal. Translation: Prado CHBA. 1st ed. São Carlos: Rima

*: Corresponding author, BANDUSHUBWENGE Denis: bandushubwengedeniis@gmail.com or

bandushubwengedenis@yahoo.com 